\title{
Acquired immunity to amyloodiniosis is associated with an antibody response
}

\author{
Charles S. Cobb, Michael G. Levy ${ }^{1, *}$, Edward J. Noga ${ }^{2}$ \\ Departments of ${ }^{1}$ Microbiology, Pathology, and Parasitology, and ${ }^{2}$ Companion Animal and Special Species Medicine, \\ North Carolina State University College of Veterinary Medicine, Raleigh, North Carolina 27606, USA
}

\begin{abstract}
The dinoflagellate Amyloodinium ocellatum, which causes amyloodiniosis or 'marine velvet disease', is one of the most serious ectoparasitic diseases plaguing warmwater marine fish culture worldwide. We report that tomato clownfish Amphiprion frenatus develop strong immunity to Amyloodinium ocellatum infection following repeated nonlethal challenges and that specific antibodies are associated with this response. Reaction of immune fish antisera against dinospore and trophont-derived antigens in Western blots indicated both shared and stage-specific antibody-antigen reactions. A mannan-binding-protein affinity column was used to isolate lgM-like antibody from $A$. frenatus serum. The reduced Ig consisted of one $70 \mathrm{kD}$ heavy chain and one $32 \mathrm{kD}$ light chain with an estimated molecular weight of $816 \mathrm{kD}$ for the native molecule. Immunoglobulin (Ig) isolated from immune but not nonimmune fish serum significantly inhibited parasite infectivity in vitro. An enzyme-linked immunosorbent assay (ELISA) was developed using polyclonal rabbit antibody produced against affinity-purified A. frenatus Ig. Anti-Amyloodinium serum antibody was not always detectable in immune fish, although serum antibody titers in immune fish increased after repeated exposure to the parasite. These results suggest that there may be a localized antibody response in skin/gill epithelial tissue, although antibody was rarely detected in skin mucus.
\end{abstract}

KEY WORDS: Amyloodinium ocellatum - Immunity Amphiprion frenatus $\cdot \mathrm{Ig}$

\section{INTRODUCTION}

Amyloodinium ocellatum (Brown, 1931) is a parasite of serious consequence in food fish mariculture and the ornamental fish trade (Noga \& Levy 1995). It is an ectoparasitic dinoflagellate with a triphasic life cycle consisting of infectious dinospore, feeding trophont and reproducing tomont stages. When fish populations are stressed as in mariculture or the ornamental fish trade, the parasite can rapidly increase and cause heavy mortality. Smith et al. (1992) showed that following injection of intact or sonically disrupted dinospores, blue tilapia Oreochromis aureus exhibited an antibody response against $A$. ocellatum. Although several species of fish exhibit increased resistance to $A$. ocellatum infection (Lawler 1977, 1980, Paperna 1980), the mechanism and dynamics of resistance have not been characterized.

\footnotetext{
·Addressee for correspondence. E-mail: mike_levy@ncsu.edu
}

Cobb et al. (1998) have shown that the tomato clownfish Amphiprion frenatus can develop immunity to Amyloodinium ocellatum infection through repeated sublethal challenges. This study was designed to address 2 questions: (1) Are specific antibodies associated with protective immune response? (2) Can specific antigens be identified which are involved in the response? Identification of specific protective antigens may facilitate development of a vaccine to prevent amyloodiniosis.

\section{MATERIALS AND METHODS}

Maintenance of fish. Aquarium-reared tomato clownfish (4 to $13 \mathrm{~g} ; 47$ to $71 \mathrm{~mm}$ total length) were initially obtained from Aqualife Resources (Ft. Lauderdale, Florida, USA) and later from C-Quest (Salinas, Puerto Rico) (2 to $4 \mathrm{~g}$; 30 to $50 \mathrm{~mm}$ ). Fish stocks were maintained in $150 \mathrm{l}$ round tanks containing 25 ppt artificial seawater (ASW). All fish were acclimated for at least 
2 wk prior to experimentation and were considered unexposed to Amyloodinium ocellatum, although their precise history was not available. Since A. ocellatum dinospores are susceptible to low levels of copper, a solution of copper sulfate was used to maintain copper levels of 0.15 to $0.20 \mathrm{mg} \mathrm{l}^{-1}$ to control ectoparasites in maintenance tanks. Parasite returns from fish maintained copper free were similar to those from fish removed from copper several days prior to infection.

Propagation of Amyloodinium ocellatum. A. ocellatum (isolate 85-1 of DC-1) was propagated in cell culture using the methods developed by Noga $(1987,1989)$.

Production of Amyloodinium ocellatum antigens. Trophont antigen: Parasites were cultured on Amphiprion frenatus and collected as described by Bower et al. (1987) with modifications described by Cobb et al. (1998), with the following exceptions. As soon as fish were removed from the specimen cups, cold $\left(4^{\circ} \mathrm{C}\right)$ ASW was added and the cups were kept on ice to arrest trophont development into tomonts. The trophonts were then counted. Whole trophonts were immediately frozen at $-70^{\circ} \mathrm{C}$. Sonicated trophonts were prepared by sonicating on ice at a setting of \#6 with a mini-probe (Branson Sonifier, Cell Disrupter 200, Danbury, CT, USA) with a cycle of $15 \mathrm{~s}$ on and $15 \mathrm{~s}$ off for a total of $3 \mathrm{~min}$. The sonicated material was centrifuged at $60 \times g$ for 5 min and the protein content of the supernatant was determined using the dotMetric ${ }^{\otimes} 1 \mu \mathrm{l}$ Protein Assay (Geno Technology, Inc., St. Louis, MO, USA). The sonicated material was then aliquoted and stored at $-70^{\circ} \mathrm{C}$

Dinospore antigen. Amyloodinium ocellatum was cultured on Amphiprion frenatus and collected as described by Bower et al. (1987). Dinospores were used either live or were sonicated as described above.

Production of anti Amyloodinium ocellatum antiserum. Antiserum to $A$. ocellatum was prepared as described by Smith et al. (1992) with the following modifications. Two groups of 10 fish each ( 3 to $4 \mathrm{~g}$ ) were injected at Weeks 0,2 and 4 with either live dinospores $\left(10^{3} \mathrm{~g}^{-1}\right.$ body wt) or whole frozen trophonts $\left(10^{2} \mathrm{~g}^{-1}\right.$ body wt). Serum was collected $4 \mathrm{~d}$ following the final injection. Antiserum was also produced by exposing 10 fish (6 to $12 \mathrm{~g}$ ) to a sublethal challenge of 40000 dinospores fish $^{-1}$ at a concentration of 200 dinospores $\mathrm{ml}^{-1}$. After $30 \mathrm{~min}$, all fish were gently removed from each container and placed in separate $38 \mathrm{l}$ holding aquaria with $25 \mathrm{ppt}$ ASW to allow the $A$. ocellatum trophonts to mature. After $3 \mathrm{~d}$, each fish was dipped in distilled water $\left(\mathrm{dH}_{2} \mathrm{O}\right)$ for $3 \mathrm{~min}$ to remove the trophonts for counting and then placed in a recovery aquarium containing 0.15 to $0.20 \mathrm{mg} \mathrm{l}^{-1}$ copper. This procedure was repeated 4 times at which time parasite recovery rate (PRR) was less than $1 \%$. Serum was collected 4,10 , and $30 \mathrm{~d}$ following the final. challenge.
Serum and mucus collection. Blood samples 150 to $300 \mu l)$ were taken from fish via the caudal vessels with a sterile, 23-gage needle attached to a $1.0 \mathrm{cc}$ syringe. Pooled blood was allowed to clot in a glass tube at room temperature for $1 \mathrm{~h}$ and then stored overnight at $4^{\circ} \mathrm{C}$. Serum was then collected by centrifugation at $1000 \times g$ for $10 \mathrm{~min}$. and then stored at $-70^{\circ} \mathrm{C}$. For ELISA analysis of serum from individual fish, serum was collected and stored as above in separate $0.5 \mathrm{ml}$ microcentrifuge tubes

Mucus was collected from individual fish with a $2 \times$ $4 \mathrm{~mm}$ piece of Gel Bond Film (FMC Corp., Rockland, $\mathrm{ME}, \mathrm{USA}$ ). The film was held at a $45^{\circ}$ angle to the skin and scraped from the operculum to the caudal fin. The fish was then turned over and the other side of the film was used to repeat the scrape. The film was then placed in a $0.5 \mathrm{ml}$ microcentrifuge tube, vortexed with $0.1 \mathrm{ml}$ phosphate buffered saline (PBS) for $10 \mathrm{~s}$ and the suspension stored at $-70^{\circ} \mathrm{C}$.

Dinospore immobilization assay. This assay was carried out as described by Smith et al. (1993b). Quadruplicate $50 \mu \mathrm{l}$, serial, doubling dilutions of each serum sample were prepared in a 96-well flat-bottom tissue culture plate using ASW/Hank's balanced salt solution (IO2/HBSS) to give final dilutions of $10 \%, 5 \%, 2.5 \%$, $1.25 \%$ and $0.61 \%$ serum concentrations. Then 200 dinospores in $50 \mu \mathrm{l}$ of IO2/HBSS were placed into each well. Motility was observed with an inverted phase contrast microscope at 5, 15,30, and 60 min and scored as 0 (majority of the dinospores immobilized), 1 (minimal effect, some slowing of movement and some immobilization), or 2 (no effect), as compared to quadruplicate wells of dinospores in IO2/HBSS without serum. Mean scores for each serum dilution were calculated for the different time intervals (Smith et al. 1993b)

Infectivity assay. To determine the toxicity of immune and non-immune tomato clownfish serum to Amyloodinium ocellatum, serum concentrations of $10 \%, 5 \%, 3 \%, 1.5 \%$ or $0.75 \%$ serum in IO2/HBSS were prepared in a 96-well cell culture plate having fish gill (G1B) cells as a feeder layer (Noga 1987, 1989). Wells containing IO2/HBSS without serum served as a control. Then 100 dinospores were added and trophonts were counted following incubation at $26^{\circ} \mathrm{C}$ for $3 \mathrm{~d}$.

To differentiate non-specific serum toxicity from a specific antibody-mediated response, 250 dinospores were exposed to affinity-purified serum $\mathrm{Ig}\left(500 \mu \mathrm{g} \mathrm{ml}^{-1}\right.$ IO2/HBSS isolated from immune or unexposed fish in a 96 -well cell-culture plate. The plate was incubated at $26^{\circ} \mathrm{C}$ and trophonts were counted on Day 3

Passive transfer of immunity. Fifty fish (8 to $14 \mathrm{~g}$ ) were rendered immune by repeated challenge of the same fish every $2 \mathrm{wk}$ for $6 \mathrm{wk}$ at which time parasite recovery rate was less than $1 \%$ (naturally immune) 
(Cobb et al. 1998). To maintain a high level of immunity, fish were challenged weekly with 10000 Amyloodinium ocellatum dinospores $\mathrm{fish}^{-1}$. In other experiments (data not shown), this regimen was shown to induce high levels of anti-dinospore and anti-trophont antibodies in an ELISA assay

Blood (50 to $100 \mu \mathrm{l}$ ) was collected from each of 50 immune fish via the caudal vessels using a $1 \mathrm{cc}$ syringe with a 23-gage needle. The blood was pooled, allowed to clot in a glass tube at room temperature for $1 \mathrm{~h}$ and then stored overnight at $4^{\circ} \mathrm{C}$. The next day serum was collected by centrifugation in pediatric serum separator tubes (Microtainer, Becton Dickinson and Company, Rutherford, NJ, USA) at $14000 \times g$ for $2 \mathrm{~min}$, then stored in $0.5 \mathrm{ml}$ aliquots at $-70^{\circ} \mathrm{C}$.

In Expt 1, $1 \mathrm{~d}$ prior to challenge, $0.1 \mathrm{ml}$ immune serum was injected (IP) into 10 fish ( 2 to $3 \mathrm{~g}$ ) which had never been experimentally challenged (naive). On the day after injection, the fish were sublethally challenged; 3 d later, PRRs were determined.

In Expt 2, 3 d prior to challenge, serum from immune fish was thawed and injected (IP) into naive fish ( 2 to $3 \mathrm{~g}$ ) at a rate of $0.1 \mathrm{ml}$ fish $^{-1}$. Injections were repeated daily for 2 additional days. On the day after the last injection, the fish were sublethally challenged $(40000$ dinospores fish ${ }^{-1}$ ); 3 d later, PRRs were determined. Sufficient quantities of naive serum were unavailable therefore sterile PBS was utilized as a negative control in these experiments.

Affinity purification of Ig. Tomato clownfish immunoglobulin (Ig) was isolated using a mannan-binding protein (MBP) affinity column following the manufacturer's instructions (ImmunoPure ${ }^{\circledR}$ IgM Purification Kit, Pierce Chemical Co., Rockford, IL, USA). Briefly, the $5 \mathrm{ml}$ column was washed with $5 \mathrm{ml}$ of ImmunoPure ${ }^{(1 B}$ MB column preparation buffer and then equilibrated with $20 \mathrm{ml}$ of ImmunoPure ${ }^{*}$ IgM binding buffer at $4{ }^{\circ} \mathrm{C}$. Gravity provided a flow rate of $1 \mathrm{ml} \mathrm{min}^{-1}$. Fish serum was diluted 1:2 with ImmunoPure ${ }^{(g M}$ binding buffer and dialyzed overnight at $4^{\circ} \mathrm{C}$ in a tris- $\mathrm{NaCl}$ buffer (10 mM Tris, 1.25 M NaCl, 0.02\% NaN $\mathrm{m}_{3}$ (Ohta et al. 1990, Nevens et al. 1992). One ml of dialyzed serum was applied to the column. After $30 \mathrm{~min}$, the column was washed with $42 \mathrm{ml}$ of binding buffer to remove unbound protein. The column was then placed at room temperature to decrease the column's binding affinity for Ig. Three ml of ImmunoPure ${ }^{\circledR}$ IgM elution buffer was added and allowed to incubate for $1 \mathrm{~h}$. In all procedures, $3 \mathrm{ml}$ fractions were collected and protein content measured using the Micro BCA Protein Assay (Pierce Chemical Co.). Eluates with significant amounts of protein ( $>10 \mu \mathrm{g} \mathrm{ml}^{-1}$ ) were pooled, and then concentrated and desalted by centrifugation (Centricon-10 micro-concentrator, Amicon, Danvers, MA, USA). The determination of protein concentration in small samples was performed by the dotMETRIC 1 ul Protein Assay. Purified Ig was stored at $-70^{\circ} \mathrm{C}$ in PBS or IO2/HBSS.

SDS-PAGE. Purified Ig was analyzed by analytical sodium dodecyl sulfate polyacrylamide gel electrophoresis (SDS-PAGE) as described by Laemmli (1970). The sample was diluted $1: 2$ with electrophoresis sample buffer $(2.3 \mathrm{ml}$ of $10 \%$ SDS, $1.0 \mathrm{ml}$ of $0.625 \mathrm{M}$ Tris$\mathrm{HCl}, \mathrm{pH} 6.8,1.0 \mathrm{ml}$ of glycerol and $5.2 \mathrm{ml}$ of distilled water with $2.5 \%$ bromophenol blue) and then added to a single well of a vertical $4 \%$ stacking gel over a $7 \%$ resolving gel (BioRad Laboratories, Richmond, CA, USA). The above procedure was modified to analyze denatured Ig by having 2-mercaptoethanol (2ME) at $2.5 \%$ in the sample buffer and boiling of the sample prior to loading. The gel was electrophoresed for 15 min at $100 \mathrm{~V}$ and then at $200 \mathrm{~V}$ until the marker dye reached the bottom of the gel. The gels were then silver-stained (Daiichi II, ISS-Emprotech, Hyde Park MA) according to manufacturer's instructions.

Western blot analysis of immune and unexposed Amphiprion frenatus serum was performed as follows. Parasite antigen (dinospore or trophont) was run on a $12 \%$ SDS-PAGE gel as previously described and transferred to a $0.2 \mu \mathrm{m}$ nitrocellulose membrane using the BioRad Modular Mini Electrophoresis System (BioRad Laboratories Richmond, CA). Following transfer, the nitrocellulose membrane was blocked with Trisbuffered saline with $0.1 \%$ Tween 20 and $0.1 \%$ gelatin (TBST/gelatin) overnight at $4^{\circ} \mathrm{C}$. The membrane was incubated for $3 \mathrm{~h}$ with $A$. frenatus serum diluted 1:5000 in TBST/gelatin. After 3 washes of $10 \mathrm{~min}$ in TBST/ gelatin, rabbit anti-tomato clownfish Ig antiserum diluted 1:5000 in TBST/gelatin was added and incubated for $2 \mathrm{~h}$ followed by another 3 washes of $10 \mathrm{~min}$ in TBST/gelatin. Horseradish peroxidase (HRP)-labeled goat anti rabbit antibody (Kirkegaard and Perry Laboratories, Inc., Gaithersburg, MD, USA) diluted 1:5000 in TBST/gelatin was added and incubated. After $2 \mathrm{~h}$, the membrane was washed 3 times with TBST/gelatin and once with Tris buffered saline (TBS).

For chemiluminescent development, the Pierce Ultra SuperSignal CL-HRP Substrate System (Pierce Chemical Co.) was used according to manufacturer's instructions. Chemiluminescent solutions $\mathrm{A}$ and $\mathrm{B}$ were mixed and added to a clean, dry incubation tray. The nitrocellulose membrane was placed into the chemiluminescent solution and rocked gently for $60 \mathrm{~s}$. The development solution was poured off and the strip was quickly wrapped with Saran Wrap ${ }^{\circledR}$ Dow Brands L.P. Indianapolis, IN, USA). A piece of X_OMAT AR scientific imaging film (Eastman Kodak Co., Rochester, NY, USA) was placed on the nitrocellulose for $1 \mathrm{~s}$. The film was developed using a Kodak M35A X_OMAT processor. 
Production of anti Amphiprion frenatus Ig antibodies. Polyclonal antibodies against $A$. frenatus Ig were produced in 2 New Zealand White rabbits by use of the RIBI Adjuvant System (RAS) (RIBI ImmunoChem Research, Inc., Hamilton, MO, USA) following the manufacturer's instructions. Briefly, the RAS formulation was reconstituted in $2 \mathrm{ml}$ of $0.15 \mathrm{M}$ PBS containing $200 \mu \mathrm{g}$ of affinity-purified Ig and warmed to $37^{\circ} \mathrm{C}$ prior to use. On Day 0, each rabbit was anesthetized by intramuscular injection with acepromazine and butorphanol $\left(0.5 \mathrm{mg} \mathrm{kg}^{-1}\right.$ of each drug) and $4 \mathrm{ml}$ of whole blood was collected prior to injecting $1 \mathrm{ml}$ of RAS divided as follows: 6 intradermal sites in the neck $(0.05 \mathrm{ml}) ; 1$ intramuscular site in each hind leg $(0.3 \mathrm{ml})$; 1 subcutaneous site in the neck $(0.1 \mathrm{ml})$. Each rabbit was boosted on Day 21 and test bled on Day 28. Exsanguination was performed under anesthesia on Day 31 using ketamine hydrochloride (Ketaset, Fort Dodge Laboratories, Inc., Fort Dodge, IA, USA) All sera were stored at $-70^{\circ} \mathrm{C}$.

Ouchterlony double diffusion. Tris-tricine buffered, ouchterlony double-diffusion gels (Monthony et al. 1978) were prepared by pipetting $8 \mathrm{ml}$ of $1 \%$ agarose onto a $75 \mathrm{~mm}$ by $53 \mathrm{~mm}$ agarose support medium (Gel Bond Film, FMC Corp., Rockland, ME). Five mm holes were punched in the agar and $20 \mu$ samples were used for the assay.

Enzyme-linked immunosorbent assay (ELISA). Stock protein concentrations were $500 \mu \mathrm{g} \mathrm{ml}^{-1}$ for dinospore antigen (Ag) and $250 \mathrm{\mu g} \mathrm{ml}^{-1}$ for trophont $\mathrm{Ag}$. The optimal concentrations of antigen (Ag), fish serum (primary antibody $[A b]$ ), rabbit serum (secondary $A b$ ) and goat anti-rabbit HRP (tertiary $A b$ ) were determined in accordance with the procedures in Smith et al. (1992). The optimal Ag and Ab dilutions were 1:1000, except for trophont Ag, which was diluted 1:500. Wells in which all reagents except fish serum were added were used to evaluate non-specific binding. ELISA values (EVs) as described by Hornitzky \& Searson (1986) were used to compare results between several ELISA plates to compensate for normal variation in plate preparation, processing and development. Positive control fish serum was generated by injecting 10 fish (6 to $12 \mathrm{~g}$ ) with $10^{3}$ live Amyloodinium ocellatum dinospores per $g$ of fish. Immunizations were performed on Weeks 0, 2, and 4. Serum was collected $4 \mathrm{~d}$ following the final injection.

ELISA analysis of mucus scrapings from fish were made as described above except that $100 \mu$ l of mucus extract in PBS was substituted for fish serum.

Fluorescent antibody assay. Three $25 \mathrm{ml}$ cell-culture flasks were seeded with G1B cells (Noga 1989). Cells were conditioned for $24 \mathrm{~h}$ and then inoculated with 50000 dinospores flask ${ }^{-1}$. After $72 \mathrm{~h}$ the medium was replaced with either: (1) serum from fish receiving re- peated nonlethal challenges diluted 1:250 in IO2/ HBSS with $0.5 \%$ bovine serum albumin (BSA); (2) unexposed fish serum diluted 1:250 in IO2/HBSS with $\mathrm{BSA}$; or (3) IO2/HBSS only with BSA. After incubation for $1 \mathrm{~h}$ at room temperature with constant gentle mixing, the detached trophonts were transferred to $15 \mathrm{ml}$ centrifuge tubes and washed 4 times with $12 \mathrm{ml}$ of IO2/HBSS using gentle centrifugation $(500 \times g$ for $5 \mathrm{~min}$ ) between each wash. Two $\mathrm{ml}$ of a 1:1000 dilution of rabbit anti-fish $\mathrm{Ab}$ in IO2/HBSS with BSA was added to each tube and incubated for $1 \mathrm{~h}$ at room temperature with constant mixing. The trophonts were washed as before. Two $\mathrm{ml}$ of a 1:1000 dilution of a 10 $\mu \mathrm{g} \mathrm{m} \mathrm{m}^{-1}$ concentration of FITC-conjugated goat anti rabbit antibody (Cappel Organon Teknika, West Chester, PA, USA) in IO2/HBSS with BSA was then added to each well and incubated for $1 \mathrm{~h}$ at room temperature with constant mixing. The trophonts were again washed 4 times and resuspended in $0.25 \mathrm{ml}$ of IO2/HBSS. Samples were mounted on slides, dried and photographed using Technical Pan 2415 film with an Olympus Vanox AH-3 photomicroscope.

Statistical analysis. Means, standard deviations from the mean and Student's $t$-test, $p$-values were calculated using Microsoft Excel for Windows.

\section{RESULTS}

\section{Purification of Amphiprion frenatus Ig}

A mannan-binding protein affinity column (Pierce Chemical Co.) successfully isolated serum Ig from both Amyloodinium ocellatum-resistant and unexposed fish. Serially eluted $3 \mathrm{ml}$ fractions were analyzed for protein content by reading optical density at $280 \mathrm{~nm}$. Fractions $2,3,4$ and 5 showed significant protein content (OD $\geq$ 0.02 at $280 \mathrm{~nm}$ ) and were pooled, concentrated, and desalted.

SDS-PAGE of reduced MBP column eluate revealed 2 bands representing the heavy and light chains of the fish immunoglobulin with little observable contamination (Fig. 1). Comparison of the bands with molecular weight standards gave estimates of $32 \mathrm{kD}$ for the light chain and $70 \mathrm{kD}$ for the heavy chain. Assuming a tetrameric structure for the intact Ig molecule, its size would be $816 \mathrm{kD}$. Tomato clownfish Ig was isolated with fewer contaminants as compared to rainbow trout Ig.

Ouchterlony double diffusion analysis of preimmune rabbit serum revealed no reactivity with fish Ig. After immunization with affinity-purified fish Ig, 2 distinct precipitation bands were observed between tomato clownfish serum and post-immunization rabbit serum. 


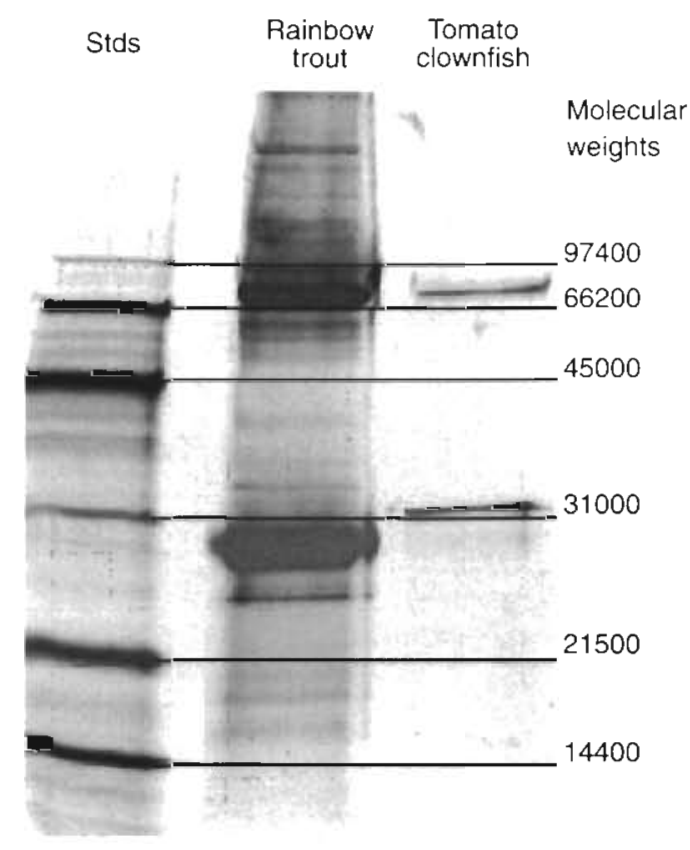

Fig. 1. SDS-PAGE of eluate from rainbow trout Oncorhynchus mykiss and tomato clownfish Amphiprion frenatus serum from an immobilized mannan-binding protein aftinity column

\section{Effects of immune serum and purified $\mathrm{Ab}$ on dinospore motility}

To evaluate anti-dinospore activity in serum from clownfish that were resistant to Amyloodinium ocellatum, we compared the activity of pooled sera from resistant fish with pooled sera from unexposed fish. Although both sera immobilized dinospores at high (>5\%) concentrations, no differences were observed between sera from immune and unexposed fish (Table 1).

Table 1. Motility index of Amyloodinium ocellatum dinospores after exposure for various times to various concentrations of immune and unexposed serum in IO2/HBSS medium (quadruplicate treatments). 0: great majority of the parasites immobilized; 1: minimal effect, some slowing of movement and some immobilization) 2 : no visible effect

\begin{tabular}{|lccccccccc|}
\hline $\begin{array}{l}\text { Serum } \\
\text { concentration }\end{array}$ & \multicolumn{3}{c}{$\begin{array}{c}\text { Serum from } \\
\text { immune fish }\end{array}$} & \multicolumn{4}{c|}{$\begin{array}{c}\text { Serum from } \\
\text { unexposed fish }\end{array}$} \\
\multicolumn{1}{c}{ Time (min): } & 5 & 15 & 30 & 60 & 5 & 15 & 30 & 60 \\
\hline $10.00 \%$ & 2 & 1 & 1 & 1 & 2 & 1 & 1 & 0 \\
$5.00 \%$ & 2 & 1 & 1 & 1 & 2 & 1 & 1 & 0 \\
$2.50 \%$ & 2 & 2 & 2 & 2 & 2 & 2 & 2 & 2 \\
$1.25 \%$ & 2 & 2 & 2 & 2 & 2 & 2 & 2 & 2 \\
$0.61 \%$ & 2 & 2 & 2 & 2 & 2 & 2 & 2 & 2 \\
$0.00 \%$ & 2 & 2 & 2 & 2 & 2 & 2 & 2 & 2 \\
\hline
\end{tabular}

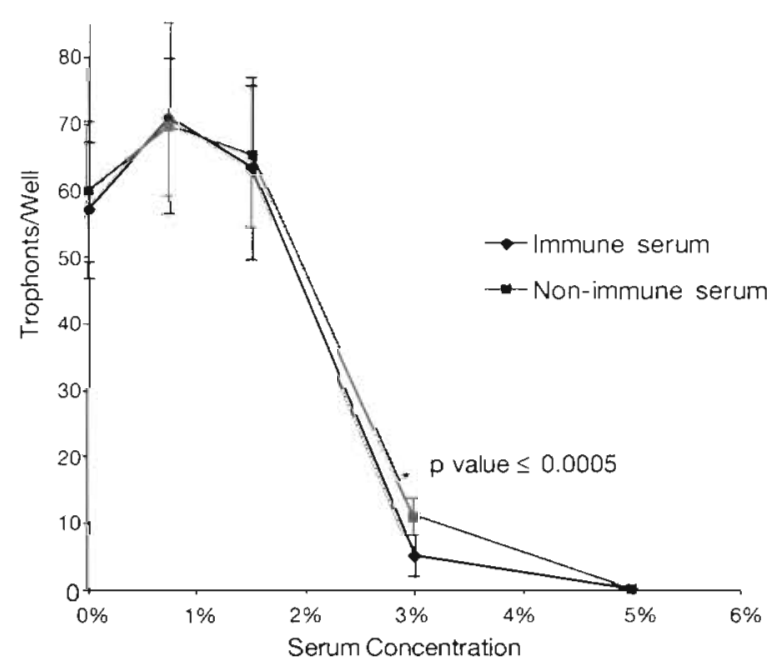

Fig. 2. In vitro infectivity of Amyloodinium ocellatum dinospores cultured with serum from immune or unexposed tomato clownfish. Serum dilutions were mixed with dinospores in a 96-well cell-culture plate having G1B cells; trophonts were counted on Day 3. Data is reported as mean number of trophonts well ${ }^{-1}( \pm \mathrm{SD})$ for each treatment group. Values with an asterisk $(*)$ were significantly $(\mathrm{p}<0.05)$ different at that serum concentration

\section{Effect of immune serum on in vitro parasite infectivity}

Incubation of dinospores with non-immune fish serum resulted in a dose-dependent reduction in infectivity, with $5 \%$ serum completely inhibiting trophont development. Immune serum caused a significantly greater inhibition $\left(4.96 \pm 3.1\right.$ trophonts well $\left.{ }^{-1}\right)$ than unexposed fish serum $\left(11.00 \pm 2.9\right.$ trophonts well $\left.{ }^{-1}\right)(\mathrm{p}$ $<0.0005$ ) (Fig. 2). Serum concentrations of 1 or $2 \%$ did not significantly reduce dinospore infectivity. When the antibody fraction of immune serum was enriched by affinity chromatography, anti-parasite activity remained strong ( $85 \%$ inhibition), whereas activity was lost when this process was performed with serum from unexposed fish (Fig. 3).

\section{Passive transfer of immunity}

In order to evaluate the effectiveness of serum from immune fish in transfer of immunity to naive fish, serum from immune fish which had been challenged weekly was injected into naïve fish. In Expt 1, fish given a single injection of immune serum $(0.1 \mathrm{ml})$ showed no transfer of immunity with a mean PRR of $7.2 \%( \pm 1.5)$ compared to PBS injected fish which had a mean PRR of $7.3 \%( \pm 2.5)(p=0.46)$. In Expt 2, PBS injected fish had a mean PRR of $13.3 \%( \pm 6.0)$ while 3 daily injections of immune serum reduced the PRR to 


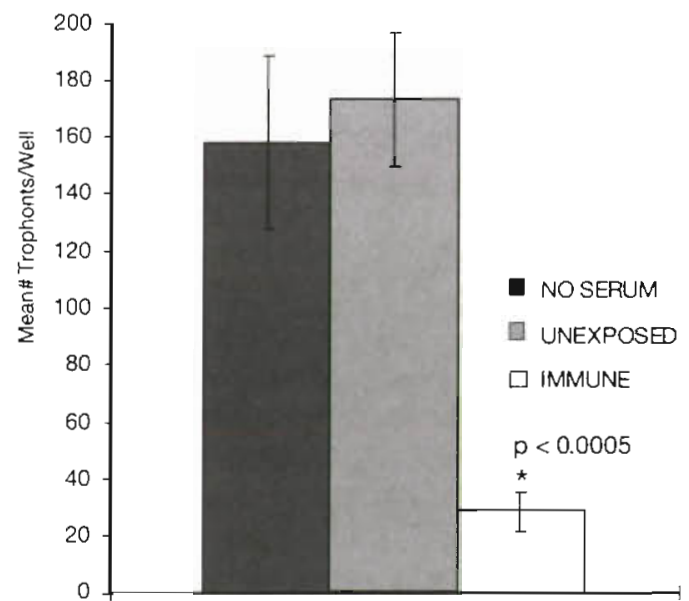

Fig. 3. Effect of MBP-purified Ig on infectivity of Amyloodinium ocellatum dinospores in vitro. Data is reported as mean number of trophonts wel! ${ }^{-1}( \pm \mathrm{SD})$ for each treatment group. $N$ $=24$ wells treatment ${ }^{-1}$ Asterisk ( $*$ ) indicates that the value is significantly $(p<0.0005)$ different from the other treatments

$7.98 \%( \pm 1.5)$. When $t$-test analysis was applied to the data a calculated p-value of 0.087 gave a confidence level of $85 \%$ that passive transfer of immunity had occurred. When one outlier in the control group and one outlier in the experimental group were removed, a p-value of 0.046 was observed (confidence level $90 \%$ ).

\section{Effect of immunization on Ab titers}

In order to measure anti Amyloodinium ocellatum serum $A b$, an ELISA was developed using the methods described by Smith et al. (1992). Preliminary studies showed that dilutions of $1: 1000$ of $\mathrm{Ag}$, primary $\mathrm{Ab}$ (fish), secondary $\mathrm{Ab}$ (rabbit), and terminal $\mathrm{Ab}$ (goat) gave optimal results. Pre-immunization rabbit serum had an average corrected optical density or COD (actual OD - OD of blank wells) of $0.003( \pm 0.002)$ while the mean post-immunization COD was $0.698( \pm 0.050)$ $(\mathrm{p}<0.0005)$.

ELISA values (EVs) as described by Hornitzky \& Searson (1986) were used to evaluate the reactivity of sonicated dinospore or sonicated trophont antigen with antiserum from fish injected with either whole dinospores or whole trophonts. Serum from fish which had 4 weekly trophont injections $\left(10^{2} \mathrm{~g}^{-1}\right.$ of fish $)$ showed no reactivity against either dinospore or trophont antigen $(\mathrm{EV}=0)$, while serum from fish which had 4 weekly injections of live dinospores $\left(10^{3} \mathrm{~g}^{-1}\right.$ of fish) had EV's of $96( \pm 28)$ against dinospore $\mathrm{Ag}$ and 37 $( \pm 16)$ against trophont $\mathrm{Ag}$.

ELISAs were performed on serum from immune fish to evaluate the kinetics of the immune response. Ten fish previously shown to be immune to Amyloodinium ocellatum challenge but which had not been challenged for $30 \mathrm{~d}$ had no detectable Ab to either dinospore or trophont $\mathrm{Ag}$, although the fish were solidly immune based on parasite recovery rate in a subsequent standard challenge. When these fish were given 2 standard challenges $1 \mathrm{wk}$ apart, they did not produce EVs above background levels. However, 4 d after a third standard challenge, EVs averaged 21 ( \pm 15$)$ against dinospore $\mathrm{Ag}$ and $30( \pm 25)$ against trophont Ag. By Day 10 after the third challenge, EVs had fallen to an average of $11( \pm 9)$ against dinospore $\mathrm{Ag}$ and to background levels against trophont Ag. ELISAs using mucus from immune fish, with only one exception, were negative (data not shown).

\section{Antibody recognition of specific parasite antigens}

Indirect fluorescent antibody showed that both trophonts and dinospores strongly fluoresced in the presence of serum from fish rendered resistant to reinfection by repeated non-lethal parasite challenges. Most trophonts uniformly fluoresced, while some fluoresced more intensely around specific areas (Fig. 4) Most dinospores uniformly fluoresced (not shown).

Serum from unexposed fish showed no reactivity to either dinospore or trophont Ag in Western blots, while serum from immune fish showed several bands of reactivity against both dinospore and trophont Ag (Fig. 5). There was a stronger reaction with dinospore Ag (more bands evident). Some bands of reactivity against trophont Ag were not evident in the dinospore Ag lane.

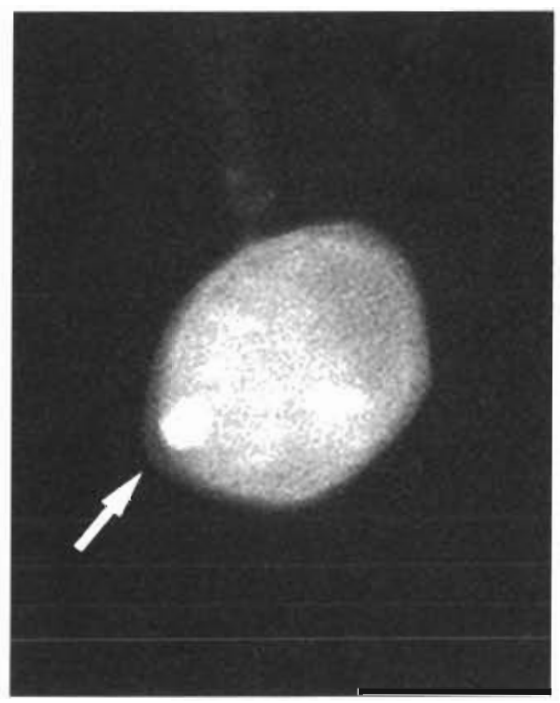

Fig. 4. Indirect fluorescent antibody analysis of immune tomato clownfish serum reacted with cell cultured trophonts Arrow indicates area of strong fluorescence 


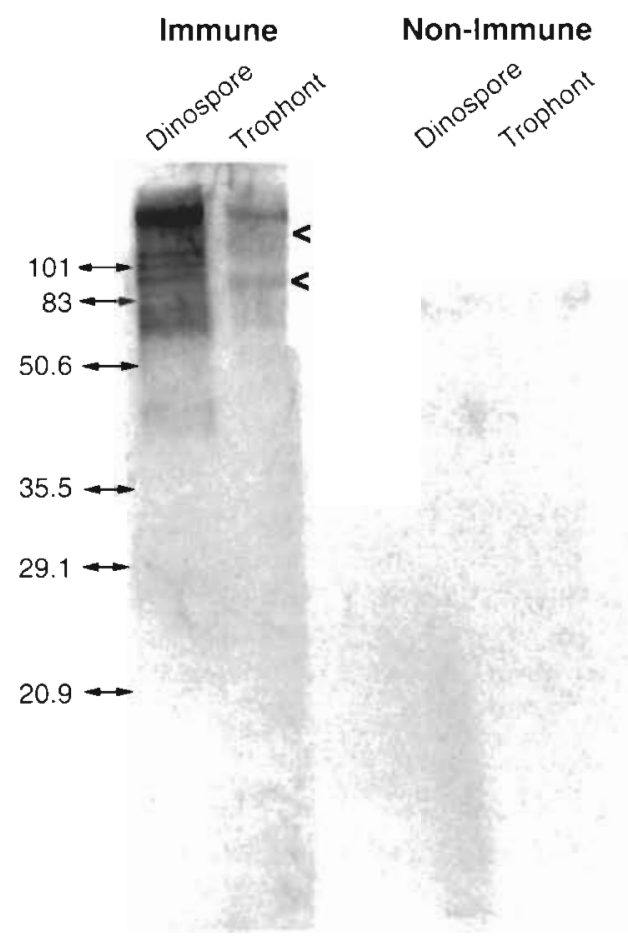

Fig. 5. Western blots of dinospore and trophont antigens reacted with immune and non-immune tomato clownfish serum. Arrowheads $(<)$ indicate trophont-specific reactions

\section{DISCUSSION}

Using tomato clownfish as a challenge model had both advantages and disadvantages. Its small size makes it easier to work with larger numbers of fish. However, since only 50 to $100 \mu$ l of blood could be collected from each fish at once, the amount of serum available was limited.

Smith et al. (1992) found a serum antibody response in blue tilapia Oreochromis aureus injected with Amyloodinium ocellatum dinospores. Serum concentrations over $10 \%$ were highly inhibitory to in vitro dinospore infectivity. This indicated that there are non-specific components found in the serum that prevent $A$. ocellatum from penetrating too deeply into tissues. Similar to the findings of Smith et al. (1993b), tomato clownfish serum inhibited dinospore infectivity at concentrations $\geq 5 \%$. Immune clownfish serum was significantly more inhibitory to parasite infectivity and/or development in vitro than control serum at $3 \%$ concentration (Fig. 2). Smith also found that serum from fish injected with dinospores immobilized dinospores more effectively than normal serum. No differences were found in dinospore immobilizing activity between naturally immune and unexposed clownfish serum. The method of immunization (dinospore injection versus live chal- lenge) was probably responsible for this difference. In our study, fish were exposed to the dinospore stage only briefly as rapid transformation to feeding trophont occurs. Furthermore, we reported that dinospores attach equally well to immune and control clownfish, suggesting that the protective immune response in vivo is not directed against dinospore attachment (Cobb et al. 1998).

In an attempt to eliminate non-specific toxicity, Ig was isolated from fish serum using an immobilized mannan-binding protein column. Affinity-purified Ig from immune fish significantly reduced dinospore infectivity while Ig isolated from unexposed fish had no effect (Fig 3). This indicates the presence of anti Amyloodinium ocellatum Ig in serum from immune fish and indicates that the non-specific inhibitory components of serum are not retained using this method of Ig isolation.

A variety of techniques have been employed in attempts to isolate piscine Ig with varying results (Acton 1971, Bradshaw et al. 1971. Clerx et al. 1980, Lobb 1981a, b, Ourth 1986, Phillips \& Ourth 1986. Havarstein et al. 1988, Smith et al. 1993a). Smith et al. (1993a) injected fish with goat IgG without an adjuvant to produce polyclonal anti-goat Ig in the fish. A goat IgG-agarose affinity column was then used to isolate the anti-goat antibodies. We failed to generate tomato clownfish anti-goat IgG antibodies we repeated the procedure (data not shown). The reason for this discrepancy is uncertain. The addition of a suitable adjuvant may be required in this species. The mannanbinding protein (MBP) affinity column varies in its ability to isolate IgM from different fish species (Wendelborn et al. 1992), with rainbow trout Oncorhynchus mykiss Ig being one of the most reliably isolated types. We found that it could be used to isolate Ig from tomato clownfish.

ELISA assays utilizing pre- and post-immunization rabbit serum confirmed the sensitivity of this assay. They also support the double diffusion assay results which indicated rabbit serum was non-reactive to tomato clownfish Ig prior to immunization and that anti tomato clownfish Ig Ab was produced after injection of rabbits with MBP column eluate. Serum from fish which were immune to Amyloodinium ocellatum following parasite challenge as well as fish injected with live dinospores reacted strongly to both dinospore and trophont antigen (data not shown). However serum from fish injected with killed trophonts failed to recognize either dinospore or trophont antigens. When trophonts are harvested from fish they quickly encyst and form an environmentally resistant tomont. The tomont may resist breakdown within the fish, reducing exposure of antigens required to stimulate antibody production. As protease inhibitors were not employed, 
the antigenicity of tomonts may have been reduced by post-preparation autolytic processes. It was previously determined that injection of live dinospores produce a greater response than dead, sonicated parasites (Smith et al. 1993b); therefore, dead trophonts also may be less antigenic. Alternatively, trophont antigens may be inherently less immunogenic.

Sera from immune fish which had not been challenged for $30 \mathrm{~d}$ did not react in the ELISA to dinospore or trophont antigen, even though the fish were solidly immune to subsequent sublethal challenge. Three weekly standard challenges were required to increase serum antibody to detectable levels. Ten days after the third challenge, average EVs to dinospore antigen had dropped to half the $4 \mathrm{~d}$ post challenge values and average EVs to trophont Ag had dropped to background levels. A wide variation in serum Ab titers between individual immune fish made the difference between Days 4 and 10 insigniticant $(p>0.05)$, but all fish were immune as measured by parasite recovery rates following sublethal challenge (data not shown).

The existence of a localized antibody response in fish has been widely proposed and studies of skin, intestine and bile (Ourth 1980, Lobb \& Clem 1981a, b, St. LouisCormier et al. 1984, Georgopoulou \& Vernier 1986, Rombout et al. 1986, Lobb 1987, Lumsden et al. 1993) have supported such a possibility. ELISA results using skin mucus from tomato clownfish were almost completely negative with only one fish showing positive results. The highly variable serum antibody levels in immune fish may indicate that protective $\mathrm{Ab}$ is produced on the body surface and Ab may only appear in serum when sufficient quantities are produced to move from these tissues into the capillaries of the blood stream as reported for mammals (Brandtzaeg 1989). The development of mucosal antibody with strong memory may require multiple exposures at the proper site (Ganguly \& Waldman 1983). In a more analogous situation, Lumsden et al. (1993) found that there was little correlation between levels of gill surface and cutaneous mucus antibody in brook trout Salvelinus fontinalis following infection with Flavobacterium branchiophilum, the etiologic agent of bacterial gill disease. Failure to detect antibody in mucus is consistent with Smith (1990), who found anti-dinospore activity in skin mucus of only $25 \%$ of tilapia immunized with dinospores. The difficulty of gill mucus collection without serum contamination from these small fish precluded direct measurement. The possibility that mucus antibody is of a different Ig subclass than serum Ig and therefore might not be reactive in the ELISA cannot be excluded. Examination of the gill for localized surface antibody production in the immune response of fish to Amyloodinium ocellatum infection must await use of a larger fish species.
Serum from immune fish but not unexposed fish strongly reacted with cell-cultured trophonts and dinospores (Fig. 4). A single injection of $0.1 \mathrm{ml}$ of immune serum $1 \mathrm{~d}$ prior to infection failed to affect parasite recovery rates $3 \mathrm{~d}$ post infection. However, when similar injections were given on a daily basis for $3 \mathrm{~d}$ prior to infection, parasite recovery rates were reduced $40 \%$ when compared to fish receiving injections of sterile PBS. The unavailability of sufficient naive serum and the necessity to substitute sterile PBS in these experiments requires that this experiment be confirmed using the proper control (naive serum). This finding, along with the inhibitory effects of immune Ig on parasite growth/development in vitro suggest that Ab may exert its strong antiparasite effects via interaction with parasite surface antigen.

Western blot analysis (Fig. 5) showed that serum from unexposed fish failed to react with dinospore or trophont antigens. Serum from immune fish reacted to several antigens from both dinospores and trophonts. The reaction to dinospores was stronger and included more antigens than the reaction to trophonts.

In summary, our data suggest that tomato clownfish can mount a protective antibody-mediated response to Amyloodinium ocellatum infection. An immobilization assay as well as an in vivo infection assay (Cobb et al. 1998) suggested that dinospores are probably not the target of the protective response. Further studies involving characterization of the immune response including the role of mucosal immunity, to $A$. ocellatum, and further identification and characterization of parasite antigens will be necessary before production of a protective vaccine will be feasible.

Acknowledgements. This work was supported by a grant from the College of Veterinary Medicine at North Carolina State University and Grant \#NA46R60087 from the National Sea Grant College Program, National Oceanic and Atmospheric Administration to the North Carolina Sea Grant Program. We thank Robin Gager, Zhiqjn Fan and David Robinette for their assistance with laboratory procedures.

\section{LITERATURE CITED}

Acton RT, Weinheimer PF, Hall SJ, Niedermier W, Shelton E, Bennett JC (1971) Tetrameric immune macroglobulins in three orders of bony fishes. Proc Natl Acad Sci 68:107-111

Bower CE, Turner DT, Biever RC (1987) A standardized method of propagating the marine fish parasite, Amyloodinium ocellatum. J Parasitol 73:85-88

Bradshaw CM, Richard AS, Sigel MM (1971) Immunologic and immunochemical studies on the gar, Lepisosteus platyrhincus. J Immunol 106:1480-1487

Brandtzaeg P (1989) Overview of the mucosal immune system. Curr Top Microbiol Immunol 146:13-25

Brown EM (1931) Note on a new species of dinoflagellate from the gills and epidermis of marine fishes. Proc Zool Soc Lond 1:345-346 
Clerx JPM, Castel A, Bol JF, Gerwig GJ (1980) Isolation and characterization of the immunoglobulin of pike (Esox lucius L). Vet Immunol Immunopathol 1:125-144

Cobb CS, Levy MG, Noga EJ (1998) Development of immunity by the tomato clownfish (Amphiprion frenatus) to the dinoflagellate parasite Amyloodinium ocellatum. J Aquat. Anim Health 10:259-263

Ganguly R, Waldman RH (1983) T-cell and B-cell memory on mucosal surfaces. Ann NY Acad Sci 409:603-611

Georgopoulou U, Vernier J (1986) Local immunological response in the posterior segment of the rainbow trout after oral administration of macromolecules. Dev Comp Immunol 10:529-537

Havarstein LS, Assjord PM, Ness S, Endresen C (1988) Purification and partial characterization of an IgM-like serum immunoglobulin from Atlantic salmon (Salmo salar). Dev Comp Immunol 12:773-785

Hornitzky M, Searson J (1986) The relationship between the isolation of Brucella abortus and serological status if infected, non-vaccinated cattle. Aust Vet J 63:172-174

Laemmli UK (1970) Cleavage of structural proteins during the assembly of the head of bacteriophage T4. Nature 227: $680-685$

Lawler AR (1977) Dinoflagellate (Amyloodinium) infestation of pompano. In: Sinderman CJ (ed) Disease diagnosis and control in North American marine aquaculture. Elsevier, Amsterdam, p 257-264

Lawler AR (1980) Studies on Amyloodinium ocellatum (Dinoflagellata) in Mississippi Sound: natural and experimental hosts. Gulf Res Rep 6:403-413

Lobb CJ (1987) Secretory immunity induced in catfish, Ictalurus punctatus, following bath immunization. Dev Comp Immunol 11: $727-738$

Lobb CJ, Clem LW (1981a) The metabolic relationships of the immunoglobulins in fish serum, cutaneous mucus and bile. J Immunol 127(4):1525-1529

Lobb CJ, Clem LW (1981b) Phylogeny of immunoglobulin structure and function $X$. Humoral immunoglobulins of the sheepshead, Archosargus probatocephalus. Dev Comp Immunol 5:271-282

Lumsden JS, Ostland VE, Byrne PJ, Ferguson HW (1993) Detection of a distinct gill-surface antibody response following horizontal infection and bath challenge of brook trout Salvelinus fontinalis with Flavobacterium branchiophilum, the causative agent of bacterial gill disease. Dis Aquat Org 16:21-27

Monthony JF, Wallace EG, Allen DM (1978) A non-barbital buffer for immunoelectrophoresis and zone electrophoresis in agarose gels. Clin Chem 24:1825-1827

Nevens JR, Mallia AK, Wendt MW, Smith PK (1992) Affinity chromatographic purification of immunoglobulin $M$ antibodies utilizing immobilized mannan-binding protein. J Chromatogr 597:247-256

Noga EJ (1987) Propagation in cell culture of the dinoflagel-

Editorial responsibility: Wolfgang Körting,

Hannover, Germany late Amyloodinium, an ectoparasite of marine fishes. Science 236:1302-1304

Noga EJ (1989) Culture conditions affecting the in vitro prop agation of Amyloodinium ocellatum. Dis Aquat Org 6: $137-143$

Noga EJ, Levy MG (1995) Dinoflagellida (Phylum Sarcomastigophora). In: Woo PTK (ed) Fish diseases and disorders. Vol 1 Protozoan and metazoan infections. $C A B$ International, Wallingford, p 1-25

Ohta M, Okada M. Ymashina I, Kawasaki T (1990) The mechanism of carbohydrate-mediated complement activation by the serum mannan-binding protein. J Biol Chem 265 $1980-1984$

Ourth DD (1980) Secretory IgM, lysozyme and lymphocityes in the skin mucus of the channel catfish, Ictalurus punctatus. Dev Comp Immunal 4:65-74

Ourth DD (1986) Purification and quantification of channel catfish (Ictalurus punctatus) immunoglobulin M. J Appl Ichthyol 3:140-143

Paperna I (1980) Amyloodinium ocellatum (Brown, 1931) (Dinoflagellida) infestations in cultured marine fish at Eilat, Red Sea: epizootiology and pathology. J Fish Dis 3 $363-372$

Phillips JO, Ourth DD (1986) Isolation and molecular weight determination of two immunoglobulin heavy chains in the channel catfish, Ictalurus puncatus. Comp Biochem Physiol 85B:49-54

Rombout JH, Blok LJ, Lamers CH, Egberts E (1986) Immunization of carp Cyprinus carpio, with a Vibrio anguil larum bacterin: indications for a common mucosal immune system. Dev Comp Immunol 10:341-351

Smith SA (1990) The immune response of blue tilapia, Oreochromis aureus to the parasitic dinoflagellate. Amyloodinium ocellatum. PhD dissertation, Dept of Companion Animal and Special Species Medicine, College of Veterinary Medicine, North Carolina State University

Smith SA, Levy MG. Noga EJ (1992) Development of an enzyme-linked immunoadsorbant assay (ELISA) for the detection of antibody to the parasitic dinoflagellate Amyloodinium ocellatum in Oreochromis aureus. Vet Parasitol 42:145-155

Smith SA, Gebhard DH, Housman JM, Levy MG, Noga EJ (1993a) Isolation, purification, and molecular-weight determination of serum immunoglobulin from Oreochromis aureus. J Aquat Anim Health 5:23-35

Smith SA, Noga EJ, Levy MG, Gerig TM (1993b) Effect of immune serum from tilapia Oreochromis aureus, immunized with dinospores of Amyloodinium ocellatum on the motility, infectivity and growth in cell culture. Dis Aquat Org 15:73-80

St Louis-Cormier EA, Osterland CK, Anderson PD (1984) Evidence for a cutaneous secretory immune system in rainbow trout (Salmo gairdneri). Dev Comp Immunol 8: $71-80$

Submitted: January 15, 1998; Accepted: June 22, 1998

Proofs received from author(s): September 25, 1998 